\title{
CHEMICAL AND MICROBIOLOGICAL EVALUATION OF SOME DIFFERENT SOFT CHEESE
}

\author{
ABO EL-MAKAREM, H.S. ${ }^{1}$, SABER, A.S. ${ }^{2}$ and EL ASUOTY, M.S ${ }^{2}$ \\ ${ }^{1}$ Lecturer at Food Hygiene Department, Fac. Vet. Med. Alex. Univ. \\ ${ }^{2}$ Researcher of Food Hygiene Unit., Animal Health Research Institute, Damanhour Branch, Egypt.
}

Received: 28 May 2017; Accepted: 6 June 2017

\begin{abstract}
The purpose of this study was to assess the chemical and microbiological quality of some different types of soft cheeses. A total of 100 samples of different soft cheeses included: Kareish, Damietta, Tallaga and double cream cheese (25 of each types) were collected randomly from Damanhour city markets, Egypt and chemically and microbiologically examined. Mean values of acidity and salt percent were $1.97 \pm 0.18,2.84 \pm 0.5 ; 1.36 \pm 0.25$, $5.01 \pm 0.25 ; 1.0 \pm 0.19,2.99 \pm 0.17$ and $0.90 \pm 0.32,1.8 \pm 0.11$ in the examined Kareish, Damietta, Tallaga and double cream cheese samples, respectively. Microbiological examination revealed that APC, Staph. aureus, coliforms, E. coli and mould counts were present in 100, 60, 48, 40, 72\% of Kareish cheese, 100, 48, 32,20, 56 $\%$ of Damietta cheese, 100, 44, 40, 24, $64 \%$ of Tallaga cheese and 100, 24, 36, 12, $40 \%$ of double cream cheese, respectively, with mean values $1.2 \times 10^{5} \pm 2 \times 10^{4}, 1.4 \times 10^{3} \pm 8 \times 10^{2}, 1.5 \times 10^{4} \pm 4 \times 10^{3}, \quad 8 \times 10^{3} \pm 3 \times 10^{3}$, $2.5 \times 10^{4} \pm 6 \times 10^{3}$ of kareish cheese, $7.8 \times 10^{4} \pm 8 \times 10^{3}, 2.8 \times 10^{3} \pm 6 \times 10^{2}, 1.6 \times 10^{3} \pm 5 \times 10^{2}, 2.0 \times 10^{2} \pm 9 \times 10,4 \times 10^{3} \pm 1 \times 10^{3}$ of Damietta cheese, $1.1 \times 10^{5} \pm 1 \times 10^{4}, 1.7 \times 10^{3} \pm 5 \times 10^{2}, 3 \times 10^{3} \pm 1 \times 10^{3}, 1.3 \times 10^{3} \pm 5 \times 10^{2}, 2.2 \times 10^{3} \pm 6 \times 10^{2}$ of Tallaga cheese and $8 \times 10^{4} \pm 1 \times 10^{4}, 4 \times 10^{2} \pm 2 \times 10^{2}, 9 \times 10^{2} \pm 3 \times 10^{2}, 1.0 \times 10^{2} \pm 6 \times 10,6 \times 10^{3} \pm 2 \times 10^{3}$ of double cream cheese, respectively. All examined samples of different kinds of soft cheese were free from listeria species. The obtained results indicated unhygienic conditions applied during production, handling and distribution of different soft cheese so, we recommended application of strict hygienic measures during all stages of production.
\end{abstract}

Key words: Soft cheese, APC, Staph. aureus, Coliforms, E. coli, moulds,

\section{INTRODUCTION}

In Egypt, soft cheese is manufactured from cow or buffalo milk or a mixture of them according to the Egyptian cheese-making technology Cheese have a great nutritional value for human consumption as its fat and protein have a high biological value and contains all essential fatty and amino acids. Also, it considered as a source of vitamins and minerals. However, cheese is very susceptible to bacterial and mould growth and is normally kept under refrigeration (Awad et al., 2012).

Damietta cheese is the most popular local type of pickled soft cheeses by all socioeconomic classes in Egypt due to its nutritional value, convenience and good taste, when fully ripned, it has strong sharp

Corresponding author: Dr. EL ASUOTY, M.S

E-mail address: mido_15158@hotmail.com

Present address: Researcher at Food Hygiene Unit., Animal Health Research Institute, Damanhour Branch, Egypt. flavor as well as smooth body and texture (Kanka et al., 2007). Also, Kareish cheese is a soft cheese commonly made and consumed in Egypt as it rich in protein, amino acids, calcium, phosphorus, vitamins and many micronutrients. Environmental conditions prevailing during storage, combined with the composition of the cheese often create possibilities for extensive development of mould on cheese surface, which reduces considerably its quality (Reps et al., 2002). The microbiological quality of cheese is influenced by initial flora of raw milk, equipment and environmental hygiene during manufacturing, packaging and handling (Robinson and Tamime 2002).

Microbial contamination of cheese may originate from various sources, during cheese production as: brine, floor, packaging material, cheese vat, cheese cloth, curd cutting knife, cold room and air of production room (Temelli et al., 2006).

Coliform bacteria are the main contaminants of raw milk and dairy products, including fresh cheeses. 
Coliforms are easily destroyed by heat treatments usually employed for milk, being an indicator of process failures or post-processing contamination in pasteurized milk (Okura et al., 2010). Among all microorganisms Escherichia coli is frequently contaminating organism, and is reliable indicator of faecal pollution generally in unsanitary conditions of water, food, milk and other dairy products (Soomro et al., 2002).

Staphylococcus aureus has a potential importance to the public health because of its ability to produce enterotoxins, resulting in staphylococcal food intoxication (Hill 1983) Presence of Staphylococcus aureus may be attributed to inadequate heat treatment, unhygienic handling practices, use of contaminated containers, faulty storage and transportation (Gill et al., 1994).

Fungal growth on cheese is a common problem for the cheese manufacture during ripening and curing as well as for the retailer and consumer during refrigeration storage. Species of Penicillium and Aspergillus are the most common contaminants of cheese (Gandomi et al., 2004). By the searching in the medical references, it was observed that, most of this fungi had the ability to induce human and animal pathogenicity or produced toxins (Ghibaudo and Peano 2010).

This study was conducted to evaluate the chemical quality and microbiological status of some locally manufactured different kinds of soft cheeses sold in Damanhur city, El-Behera governorate, Egypt, including Kareish, Damietta, Tallaga and double cream cheese, such cheese is mostly contaminated with different types of organisms gaining access to the product from various sources during production, handling and distribution.

\section{MATERIALS AND METHODS}

\section{Collection of samples:}

A total of 100 samples of different cheese (Kareish, Damietta, Tallaga and double cream cheese samples) 25 of each were collected randomly from supermarkets, and street-vendors at Damanhour city, Egypt. The samples were transferred directly in an icebox at $4 \pm 1{ }^{\circ} \mathrm{C}$ to the laboratory with a minimum of delay to be examined. Preparation of the samples was carried out according to (APHA 2004).

2. Chemical evaluation of examined cheese samples: Salt content was determined according to AOAC (2005) and determination of acidity percent according to Atherton and Newlander (1977).

\section{Microbiological evaluation of examined cheese samples:}

Representative $10 \mathrm{~g}$. of each sample was aseptically homogenized in $90 \mathrm{ml}$ of a sterile $2 \%$ sodium citrate solution, in a stomacher for 1 minute. Decimal dilutions were prepared in $0.1 \%$ sterile peptone water and appropriate dilutions were used to enumerate the following as descried by Roberts and Greenwood (2003).

3.1. Aerobic plate count (APC) was carried out as the conventional method, FDA (2002) using plate count agar (Oxoid).

3.2. Staphylococcus aureus was counted using Baird Parker medium after incubation at $35^{\circ} \mathrm{C}$ for $24-48$ hours (Oxoid 2006).

3.3. Coliforms count was determined using plate method onto plates of violet red bile agar (Difco) according to the method reported by FDA (2002).

3.4. E.coli count on Eosin Methylene Blue Agar (E.M.B.) at $35 \pm 0.5{ }^{\mathrm{O}} \mathrm{C}$ for 24 hours according to FDA (2002).

\subsection{Mould count according to (APHA 2004).}

3.6. Isolation and identification of listeria species according to the methods prescribed by (Hitchins 2003).

\section{Statistical analysis:}

The results are expressed as the mean \pm SE. Data analysis was preformed SPSS program (2008) (Statistical Package for Social Science, version 10).

\section{RESULTS}

Results are illustrated in Tables (1-8) and Fig. (1-5).

Table 1: Statistical analytical results of acidity percent of different examined soft cheese samples ( $\mathrm{n}=25$ of each).

\begin{tabular}{lccc}
\hline \multirow{2}{*}{ Sample category } & \multicolumn{3}{c}{ Acidity percent } \\
\cline { 2 - 4 } & Minimum & Maximum & Mean \pm SEM \\
\hline Kareish cheese & 1.4 & 2.9 & $1.97 \pm 0.18$ \\
\hline Damietta cheese & 0.25 & 2.5 & $1.36 \pm 0.25$ \\
\hline Tallaga cheese & 0.50 & 1.9 & $1.0 \pm 0.19$ \\
\hline Double cream chees & 0.30 & 1.20 & $0.90 \pm 0.32$ \\
\hline
\end{tabular}


Table 2: Statistical analytical results of salt content of different examined soft cheese samples ( $\mathrm{n}=25 \mathrm{of}$ each).

\begin{tabular}{lccc}
\hline \multicolumn{1}{c}{ Sample category } & \multicolumn{3}{c}{ Salt content } \\
\cline { 2 - 4 } & Minimum & Maximum & Mean \pm SEM \\
\hline Kareish cheese & 0.45 & 5.20 & $2.84 \pm 0.5$ \\
\hline Damietta cheese & 3.90 & 6.50 & $5.01 \pm 0.25$ \\
\hline Tallaga cheese & 2.10 & 3.70 & $2.99 \pm 0.17$ \\
\hline Double cream chees & 1.30 & 2.20 & $1.8 \pm 0.11$ \\
\hline
\end{tabular}

Table 3: Statistical analytical results of APC (cfu/g) of different types of soft cheese ( $\mathrm{n}=25$ of each).

\begin{tabular}{lccc}
\hline \multirow{2}{*}{ Sample category } & \multicolumn{3}{c}{ Aerobic plate count } \\
\cline { 2 - 4 } & Minimum & Maximum & Mean \pm SEM \\
\hline Kareish cheese & $2.7 \times 10^{4}$ & $2.9 \times 10^{5}$ & $1.2 \times 10^{5} \pm 2 \times 10^{4}$ \\
\hline Damietta cheese & $5.5 \times 10^{3}$ & $1.3 \times 10^{5}$ & $7.8 \times 10^{4} \pm 8 \times 10^{3}$ \\
\hline Tallaga cheese & $2.5 \times 10^{4}$ & $2.2 \times 10^{5}$ & $1.1 \times 10^{5} \pm 1 \times 10^{4}$ \\
\hline Double cream cheese & $4.3 \times 10^{3}$ & $1.5 \times 10^{5}$ & $8 \times 10^{4} \pm 1 \times 10^{4}$ \\
\hline
\end{tabular}

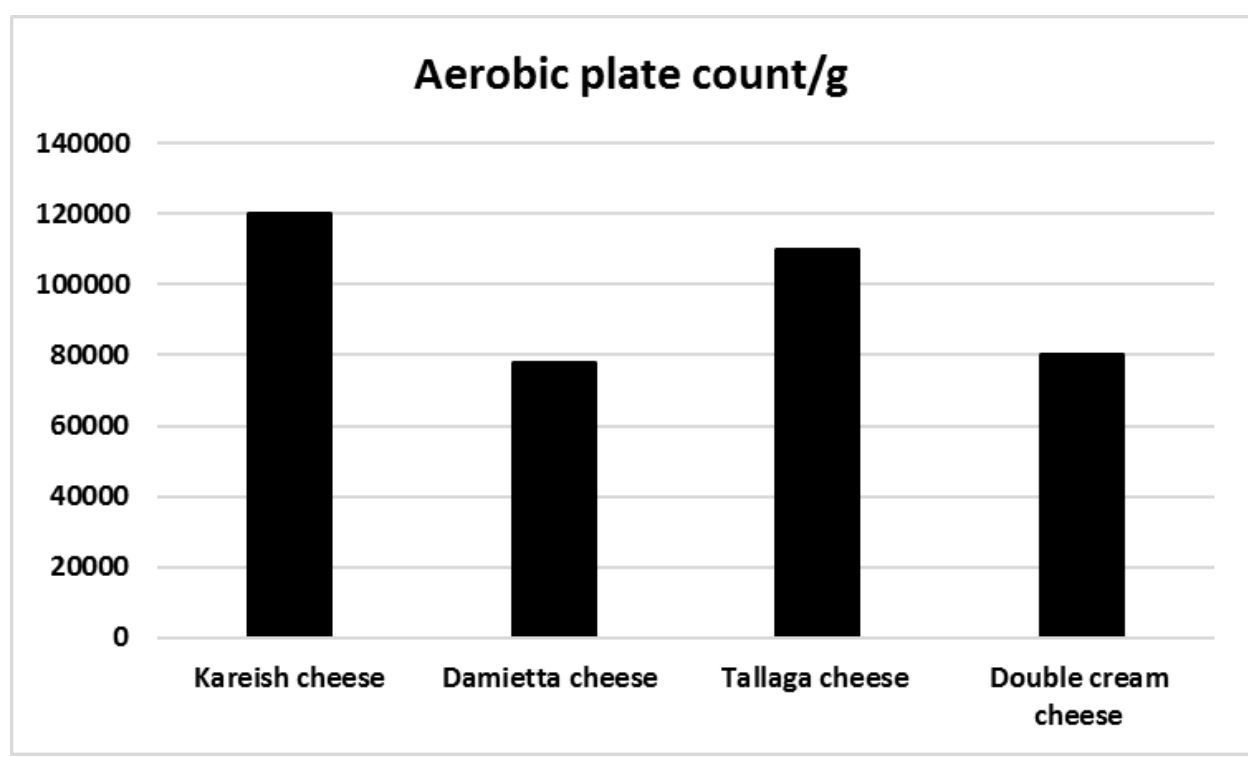

Fig. 1: Mean values APC (cfu/g) for different Egyptian soft cheese

Table 4: Statistical analytical results of Staph. aureus count /g of different types of soft cheese ( $\mathrm{n}=25 \mathrm{of}$ each).

\begin{tabular}{lccccc}
\hline \multirow{2}{*}{\multicolumn{1}{c}{ Sample category }} & \multicolumn{2}{c}{$\begin{array}{c}\text { Positive } \\
\text { samples }\end{array}$} & \multicolumn{3}{c}{ Staphylococcus aureus count/g } \\
\cline { 2 - 6 } & No & $\%$ & Minimum & Maximum & Mean \pm SEM \\
\hline Kareish cheese & 15 & 60 & $<100 \mathrm{cfu} / \mathrm{g} *$ & $2.1 \times 10^{4}$ & $1.4 \times 10^{3} \pm 8 \times 10^{2}$ \\
\hline Damietta cheese & 12 & 48 & $<100 \mathrm{cfu} / \mathrm{g}^{*}$ & $9.8 \times 10^{3}$ & $2.8 \times 10^{3} \pm 6 \times 10^{2}$ \\
\hline Tallaga cheese & 11 & 44 & $<100 \mathrm{cfu} / \mathrm{g}^{*}$ & $8.3 \times 10^{3}$ & $1.7 \times 10^{3} \pm 5 \times 10^{2}$ \\
\hline Double cream cheese & 6 & 24 & $<100 \mathrm{cfu} / \mathrm{g}^{*}$ & $3.0 \times 10^{3}$ & $4 \times 10^{2} \pm 2 \times 10^{2}$ \\
\hline
\end{tabular}

* Calculated as zero in statistical analysis 


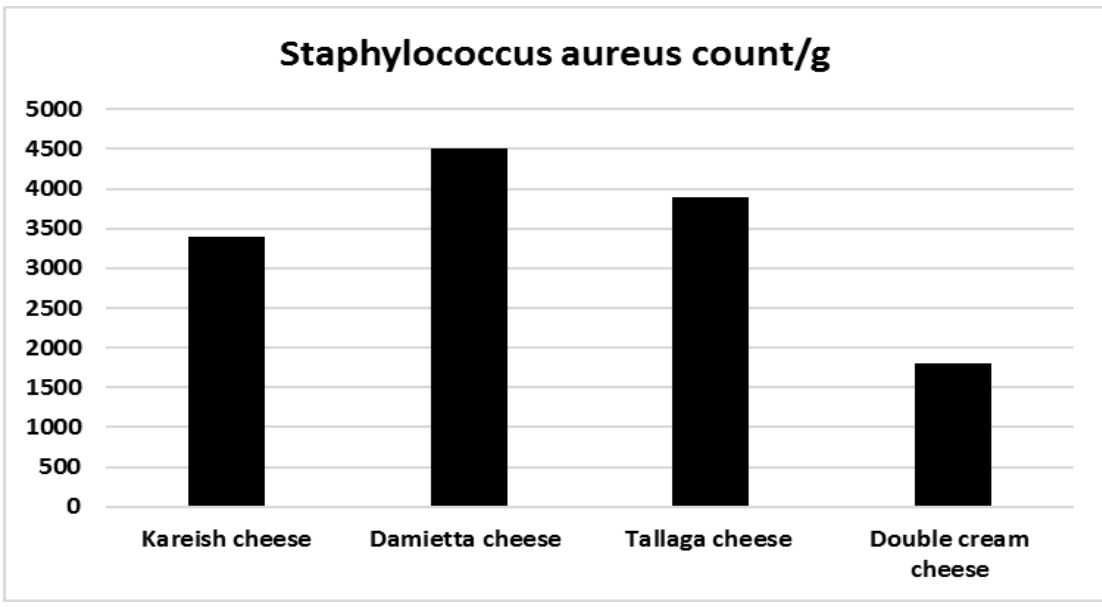

Fig. 2: Mean values of Staphylococcus aureus count for different soft cheese.

Table 5: Statistical analytical results of total Coliforms count /g of different types of soft cheese ( $\mathrm{n}=25 \mathrm{of}$ each).

\begin{tabular}{|c|c|c|c|c|c|}
\hline \multirow[t]{2}{*}{ Sample category } & \multicolumn{2}{|c|}{$\begin{array}{l}\text { Positive } \\
\text { samples } \\
\end{array}$} & \multicolumn{3}{|c|}{ Total coliforms count /g } \\
\hline & No & $\%$ & Minimum & Maximum & Mean \pm SEM \\
\hline Kareish cheese & 12 & 48 & $<10 \mathrm{cfu} / \mathrm{g}^{*}$ & $7.2 \times 10^{4}$ & $1.5 \times 10^{4} \pm 4 \times 10^{3}$ \\
\hline Damietta cheese & 8 & 32 & $<10 \mathrm{cfu} / \mathrm{g}^{*}$ & $8.8 \times 10^{3}$ & $1.6 \times 10^{3} \pm 5 \times 10^{2}$ \\
\hline Tallaga cheese & 10 & 40 & $<10 \mathrm{cfu} / \mathrm{g}^{*}$ & $2.0 \times 10^{4}$ & $3 \times 10^{3} \pm 1 \times 10^{3}$ \\
\hline Double cream cheese & 9 & 36 & $<10 \mathrm{cfu} / \mathrm{g}^{*}$ & $4.4 \times 10^{3}$ & $9 \times 10^{2} \pm 3 \times 10^{2}$ \\
\hline
\end{tabular}

* Calculated as zero in statistical analysis

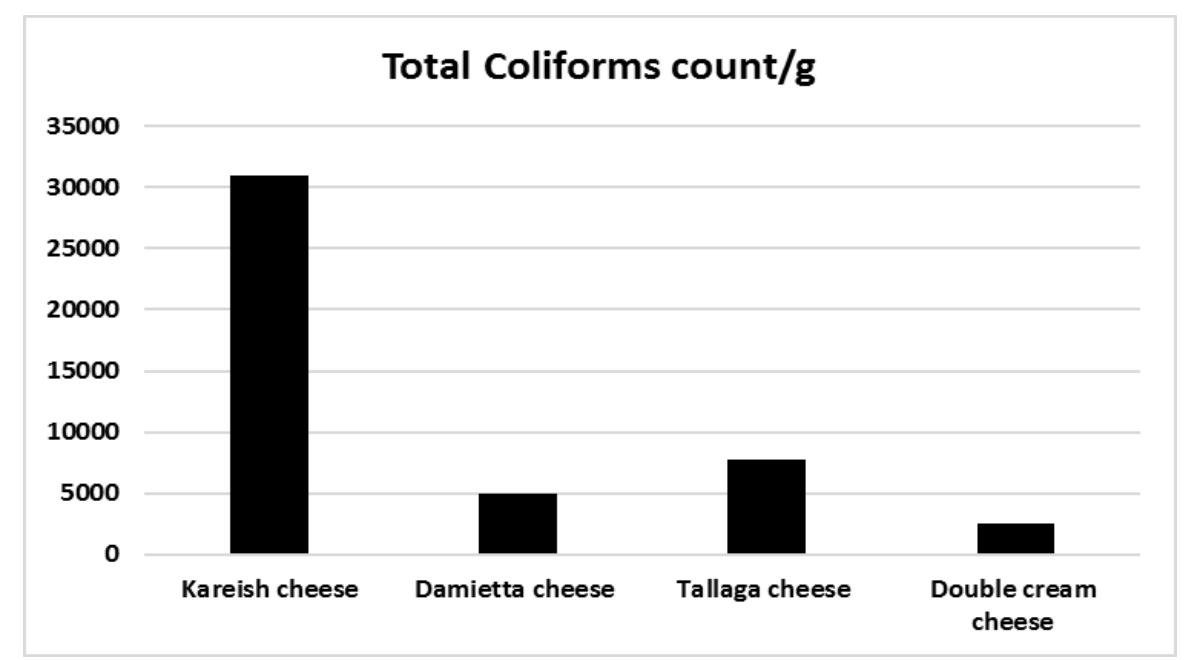

Fig. 3: Mean values of total Coliforms count for different soft cheese.

Table 6: Statistical analytical results of $E$. coli count/g of different types of soft cheese (n=25 of each).

\begin{tabular}{lccccc}
\hline \multirow{2}{*}{\multicolumn{1}{c}{ Sample category }} & \multicolumn{2}{c}{$\begin{array}{c}\text { Positive } \\
\text { Samples }\end{array}$} & \multicolumn{2}{c}{ E.coli/g } \\
\cline { 2 - 6 } & No & $\%$ & Minimum & Maximum & Mean \pm SEM \\
\hline Kareish cheese & 10 & 40 & $<10 \mathrm{cfu} / \mathrm{g}^{*}$ & $4.5 \times 10^{4}$ & $8 \times 10^{3} \pm 3 \times 10^{3}$ \\
\hline Damietta cheese & 5 & 20 & $<10 \mathrm{cfu} / \mathrm{g}^{*}$ & $2.0 \times 10^{3}$ & $2.0 \times 10^{2} \pm 9 \times 10$ \\
\hline Tallaga cheese & 6 & 24 & $<10 \mathrm{cfu} / \mathrm{g}^{*}$ & $9.0 \times 10^{3}$ & $1.3 \times 10^{3} \pm 5 \times 10^{2}$ \\
\hline Double cream cheese & 3 & 12 & $<10 \mathrm{cfu} / \mathrm{g}^{*}$ & $1.3 \times 10^{3}$ & $1.0 \times 10^{2} \pm 6 \times 10$ \\
\hline
\end{tabular}

* Calculated as zero in statistical analysis 


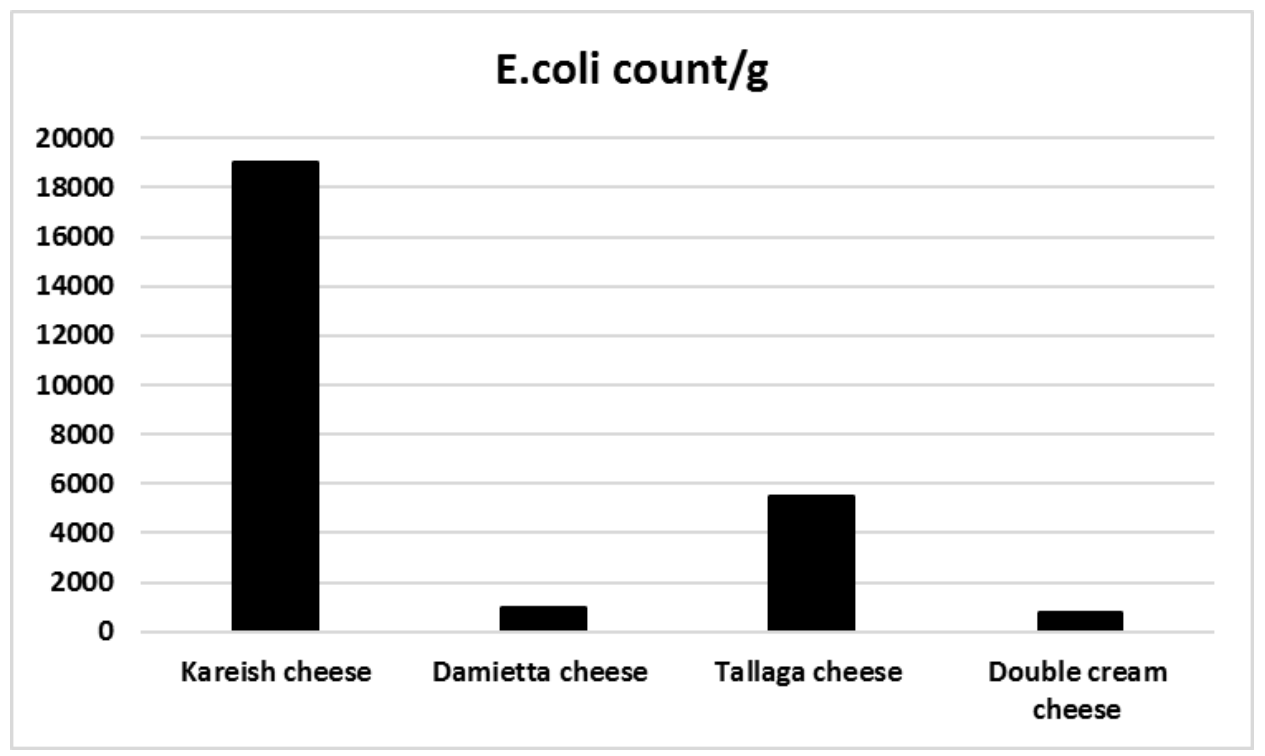

Fig. 4: Mean values of $E$. coli count for different soft cheese.

Table 7: Statistical analytical results total mould count /g of different types of cheese ( $\mathrm{n}=25$ of each).

\begin{tabular}{lccccc}
\hline \multirow{2}{*}{ Sample category } & \multicolumn{2}{c}{$\begin{array}{c}\text { Positive } \\
\text { samples }\end{array}$} & \multicolumn{2}{c}{ Total mould count $/ g$} \\
\cline { 2 - 6 } & No & $\%$ & Minimum & Maximum & Mean \pm SEM \\
\hline Kareish cheese & 18 & 72 & $<10 \mathrm{cfu} / \mathrm{g} *$ & $9.5 \times 10^{4}$ & $2.5 \times 10^{4} \pm 6 \times 10^{3}$ \\
\hline Damietta cheese & 14 & 56 & $<10 \mathrm{cfu} / \mathrm{g}^{*}$ & $2.0 \times 10^{4}$ & $4 \times 10^{3} \pm 1 \times 10^{3}$ \\
\hline Tallaga cheese & 16 & 64 & $<10 \mathrm{cfu} / \mathrm{g}^{*}$ & $1.5 \times 10^{4}$ & $2.2 \times 10^{3} \pm 6 \times 10^{2}$ \\
\hline Double cream cheese & 10 & 40 & $<10 \mathrm{cfu} / \mathrm{g} *$ & $3.0 \times 10^{4}$ & $6 \times 10^{3} \pm 2 \times 10^{3}$ \\
\hline
\end{tabular}

* Calculated as zero in statistical analysis

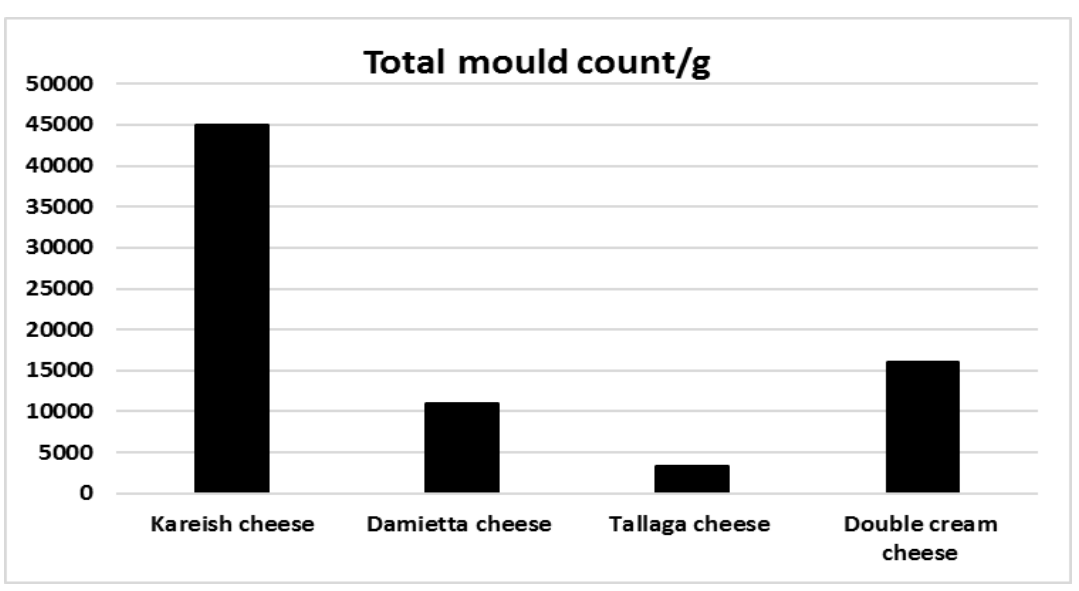

Fig. 5: Mean values of total mould count for different types of soft cheese 
Table 8: Comparison the obtained results of coliforms, staph. aureus, E. coli and yeast and moulds in different examined soft cheese with Egyptian standard, 2005.

\begin{tabular}{|c|c|c|c|c|c|c|}
\hline \multicolumn{7}{|c|}{ Coliforms count } \\
\hline \multirow[t]{2}{*}{ Products } & \multirow{2}{*}{$\begin{array}{c}\text { No. of } \\
\text { examined } \\
\text { samples }\end{array}$} & \multirow[t]{2}{*}{$\begin{array}{l}\text { Egyptian Standard, } \\
\qquad(2005)\end{array}$} & \multicolumn{2}{|c|}{$\begin{array}{l}\text { Comply with } \\
\text { Egyptian } \\
\text { standards }\end{array}$} & \multicolumn{2}{|c|}{$\begin{array}{l}\text { Not comply with } \\
\text { Egyptian } \\
\text { standard }\end{array}$} \\
\hline & & & NO & $\%$ & NO & $\%$ \\
\hline Kareish cheese & 25 & $10 \mathrm{cfu} / \mathrm{g}$ & 13 & 52 & 12 & 48 \\
\hline Damietta cheese & 25 & $10 \mathrm{cfu} / \mathrm{g}$ & 17 & 68 & 8 & 32 \\
\hline Tallaga cheese & 25 & $10 \mathrm{cfu} / \mathrm{g}$ & 15 & 60 & 10 & 40 \\
\hline Double cream cheese & 25 & $10 \mathrm{cfu} / \mathrm{g}$ & 16 & 64 & 9 & 36 \\
\hline \multicolumn{7}{|c|}{ Staphylococcus aureus count } \\
\hline Kareish cheese & 25 & Free & 10 & 40 & 15 & 60 \\
\hline Damietta cheese & 25 & Free & 13 & 52 & 12 & 48 \\
\hline Tallaga cheese & 25 & Free & 14 & 56 & 11 & 44 \\
\hline Double cream cheese & 25 & Free & 19 & 76 & 6 & 24 \\
\hline \multicolumn{7}{|c|}{ E. coli count } \\
\hline Kareish cheese & 25 & Free & 15 & 60 & 10 & 40 \\
\hline Damietta cheese & 25 & Free & 20 & 80 & 5 & 20 \\
\hline Tallaga cheese & 25 & Free & 19 & 76 & 6 & 24 \\
\hline Double cream cheese & 25 & Free & 22 & 88 & 3 & 12 \\
\hline \multicolumn{7}{|c|}{ listeria species } \\
\hline Four Types of cheese & 100 & Free & 100 & 100 & 0 & 0 \\
\hline \multicolumn{7}{|c|}{ Mould counts } \\
\hline Kareish cheese & 25 & Not more than $10 \mathrm{cfu} / \mathrm{g}$ & 7 & 28 & 18 & 72 \\
\hline Damietta cheese & 25 & Not more than $10 \mathrm{cfu} / \mathrm{g}$ & 11 & 44 & 14 & 56 \\
\hline Tallaga cheese & 25 & Not more than $10 \mathrm{cfu} / \mathrm{g}$ & 9 & 36 & 16 & 64 \\
\hline Double cream cheese & 25 & Not more than $10 \mathrm{cfu} / \mathrm{g}$ & 15 & 60 & 10 & 40 \\
\hline
\end{tabular}

\section{DISCUSSION}

Results recorded in Table 1 revealed that the mean value of titera table acidity percent of examined kareish, Damietta, Tallaga and double cream cheeses samples were $1.97 \pm 0.18,1.36 \pm 0.25,1.0 \pm 0.19$ and $0.90 \pm 0.32$, respectively, with a range of 1.4 to $2.9,0.25$ to $2.5,0.50$ to 1.9 and 0.30 to $1.20 \%$ respectively.

Lower acidity percent of kareish and Damietta cheese obtained by Salama et al. (2015) as they found that the mean values of acidity $\%$ in Kareish cheese and Damietta cheese were $0.79 \pm 0.04$ and $0.72 \pm 0.039 \%$.

High acidity percent of some examined kareish cheese samples may attributed to the method of its manufacture (farm method) in which skim milk is kept for about 36 hours at room temperature giving the chance for lactic acid or other bacteria to grow and produce acid as its manufacture depends upon acid coagulation (Amer 2002). Relative variations in acidity percent of the examined Damietta cheese samples may be attributed to variation in manufacturing process, ripening periods, temperature of storage and/ or age of cheese samples (Mohamed 2016). Generally, delayed manufacturing process, prolonged ripening period, warm storage temperature and aging of cheese increasing the acidity percent of such product (Mohamed 2016).

Results presented in Table 2 showed that the mean values of salt content of examined Kareish, Damietta, Tallaga and Double cream cheese samples were 2.84 $\pm 0.5,5.01 \pm 0.25,2.99 \pm 0.17$ and $1.8 \pm 0.11$, respectively. With a range of 0.45 to $5.20,3.90$ to $6.50,2.10$ to 3.70 and 1.30 to $2.20 \%$, respectively. According to Egyptian standard (1008-3/2005) which stipulated that salt content in Damietta cheese should not be more than 9\%, all examined Damietta cheese samples were within the permissible limit.

Higher salt content of kareish cheese obtained by Salama et al. (2015) they reported that the mean value of sodium chloride content was 5.28 \pm 0.14 , while the obtained result of salt content in Damietta cheese nearly similar to mean value of sodium chloride content obtained by Salama et al. (2015) they reported that mean values of sodium chloride content was $5.10 \pm 0.130$. 
The microbiological quality of white soft cheese in different Egyptian varieties affected by different salt concentrations, acidity percent as kareish cheese is acid coagulated while Damietta cheese is enzyme coagulated, ripening in brine solutions and keeping temperatures (El-Sayed et al., 2011).

Data in Table 3revealed that the APC was detected in all examined samples of Kareish, Damietta, Tallaga and double cream cheese, ranged between $2.7 \times 10^{4}$ and $2.9 \times 10^{5}, 5.5 \times 10^{3}$ and $1.3 \times 10^{5}, 2.5 \times 10^{4}$ and $2.2 \times 10^{5}, 4.3 \times 10^{3}$ and $1.5 \times 10^{5} \mathrm{cfu} / \mathrm{gm}$, with mean value of $1.2 \times 10^{5} \pm 2 \times 10^{4}, 7.8 \times 10^{4} \pm 8 \times 10^{3}, 1.1 \times 10^{5} \pm 1$ x $10^{4}$ and $8 \times 10^{4} \pm 1 \times 10^{4} \mathrm{cfu} / \mathrm{gm}$, respectively.

The present data of kareish cheese are in agreement with those obtained by El-Sayed et al. (2011). Higher results of APC in kareish cheese was obtained by Metwalli (2011) who found that the APC of Kareish cheese ranged between 50 and $21 \times 10^{7} \mathrm{cfu} / \mathrm{gm}$. Also, Hassan and Gomaa (2016) reported thattotal colony count of examined Damietta cheese in Cairo was ranged from $9 \times 10^{2}$ to $3 \times 10^{6}$ with a mean value of $1.7 \times 10^{5} \pm 9.6 \times 10^{4}$. Higher results of APC in kareish cheese reported by Baraheem et al. (2007) who reported that the mean $\pm \mathrm{SD}$ of $\mathrm{APC}$ in opened and packaged kareish cheese were $1.1 \times 10^{9} \pm 1.6 \times 10^{9}$ and $2.4 \times 10^{8} \pm 7.4 \times 10^{8}$, respectively and, Hassan and Gomaa (2016) reported that total colony count of Kareish cheese samples in Cairo was ranged from $2 \times 10^{2}$ to $1 \times 10^{7}$ with a mean value of $1.7 \times 10^{6} \pm$ $3.8 \times 10^{5}$.

The relatively high total bacterial count in the examined cheese samples revealed that such cheese exposed to contamination during the various stages of production, handling and distribution (Halawa and Moawad 1999). Soft cheese with high $\mathrm{pH}$ value and high moisture content will support growth of a wide range of microorganisms (Varnam and Sutherland 1994).

Regarding to data in Table 4 The incidence of Staphylococcus aureus were 60, 48, 44 and $24 \%$ in Kareish, Damietta, Tallaga and double cream cheeses samples, respectively, with respective mean values $1.4 \times 10^{3} \pm 8 \times 10^{2}, 2.8 \times 10^{3} \pm 6 \times 10^{2}, 1.7 \times 10^{3} \pm 5 \times 10^{2}$ and $4 \times 10^{2} \pm 2 \times 10^{2} \mathrm{cfu} / \mathrm{g}$. While its range were $<100$ to $2.1 \times 10^{4},<100$ to $9.8 \times 10^{3}$, $<100$ to $8.3 \times 10^{3}$ and $<100$ to $3.0 \times 10^{3} \mathrm{cfu} / \mathrm{g}$, respectively. Egyptian Standards (2005) which stated that white soft cheese must be free from Staph. aureus, according to this standard 60, 48,44 and 24\% of examined Kareish, Damietta, Tallaga and double cream cheeses samples were incompatible with this limit (Table 8), this mean that all positive samples for Staph. aureus was incompatible with this limits. Presence of Staph. aureus in cheese may be due to contamination during processing, insufficient pasteurization or from use bad quality starter culture.
Sayed et al. (2011) reported that 28 and $84 \%$ of the examined Damietta and Tallaga cheese samples had Staph. aureus above the allowed limit stated with Egyptian standard, with a mean values $1.7 \times 10^{4}$ and $3.2 \times 10^{5}$, respectively. Hassan and Gomaa (2016) detected Staphylococcus aureus in 49(98\%) and $50(100 \%)$ of examined Damietta cheese samples in Cairo and Giza with a range $\left(4 \times 10^{2}-4.3 \times 10^{5}\right)$ and from $\left(6 \times 10^{2}\right.$ to $\left.7 \times 10^{7}\right)$, respectively, while in kareish cheese samples Staph. aureus was isolated from all examined samples with a range of $\left(1.2 \times 10^{2}-8.1 \times 10^{4}\right)$ and $\left(3 \times 10^{2}\right.$ to $\left.8.2 \times 10^{5}\right)$ in Cairo and Giza, respectively.

Presence of large number of Staph. aureus in dairy products is considered a good indicator of personal hygiene of workers with respiratory infections (Kamat et al. 1991). Generally, Differences between the results may be based on the differences in the cheese production techniques, storage conditions; type of cheese and whether the milk used was raw or pasteurized. It could be also related to the unclean conditions where the cheese is produced and the personnel involved in production.

Staphylococcal cells can be introduced into raw milk cheeses through one of three pathways: The presence of staphylococcal cells in the raw milk used to produce the cheese; Cross contamination from an infected cheese maker or food handler during or after cheese making cross contamination of contaminated surfaces/machinery during cheese making (Paulin et al., 2011).

Data in Table 5 showed that the incidence of total Coliforms group were 48, 32, 40 and $20 \%$ in the examined Kareish, Damietta, Tallaga and double cream cheeses samples, with a mean values of $1.5 \times 10^{4} \pm 4 \times 10^{3}, \quad 1.6 \times 10^{3} \pm 5 \times 10^{2}, \quad 3 \times 10^{3} \pm 1 \times 10^{3}$ and $9 \times 10^{2} \pm 3 \times 10^{2}$, respectively. The Standard Egyptian Guidelines allow maximum possible of Coliforms bacterial count in cheese which up to 10 cells/ g. according to these standard 48, 32, 40 and $36 \%$ of examined Kareish, Damietta, Tallaga and double cream cheeses samples were not comply with Egyptian standards table (8).

Sayed et al. (2011) reported that 12and $40 \%$ of examined Damietta and Tallaga cheese had coliforms count above limits stated by Egyptian standard with mean values of 82.4 and $2.64 \times 10^{2}$, respectively. Baraheem et al. (2007) reported that incidence of total coliforms was $54(67.5 \%)$ of examined kareish cheese samples with mean \pm SD of $7.3 \times 10^{2} \pm 9.9 \times 10^{2}$ and $1.6 \times 10^{2} \pm 5.6 \times 10^{2}$ in opened and packaged kareish cheese respectively. El Sayed et al. (2011) found that coliform group and Escherichia coli as fecal indicator contamination were implicated in 50 and $24 \%$ of the retailed white soft cheese samples, respectively. Hassan and Gomaa (2016) revealed that coliforms were present in Damietta cheese samples in $45(90 \%)$ 
and $50(100 \%)$ and ranged from $3 \times 10^{2}$ to $5.5 \times 10^{5}$ with a mean value of $2.7 \times 10^{4} \pm 1.2 \times 10^{4}$ and from $1 \times 10^{2}$ to $2.2 \times 10^{5}$ with a mean value of $1.6 \times 10^{4} \pm$ $2.3 \times 10^{3}$ in Cairo and Giza cheese samples while in Kareish cheese all examined samples were contaminated with coliforms with a count ranged from $7 \times 10^{2}$ to $1.8 \times 10^{7}$ with a mean value of $6.1 \times 10^{5} \pm$ $3.5 \times 10^{5}$ and from $1 \times 10^{2}$ to $8 \times 10^{6}$ with a mean value of $5.8 \times 10^{5} \pm 2 \times 10^{5}$ in Cairo and Giza samples respectively.

High contamination of Kareish cheese with coliforms may be due to the fact that Kareish cheese is sold uncovered and without container which made it good medium for growth and multiplication of different types of spoilage and pathogenic microorganisms (Ibrahim et al., 2015). The variation in total coliforms between Kareish, Damietta, Tallaga and double cream cheeses may be due to the difference in salt concentrations, acidity, and the method of manufacture. Additionally, ripening in brine solution, quality and heat treatment of milk used in the manufacture, handling method, hygienic practices, transportation condition, storage condition and distribution play an important role in its microbial quality.

Coliforms including faecal coliforms and E. coli have probably received more attention than most other groups of bacteria owing to their importance as indicator species in routine analysis to ascertain the quality of cheese (Synge 2000).

Data presented in Table 6revealed that the incidence of $E$. coli was 40, 20, 24 and $12 \%$ in the examined Kareish, Damietta, Tallaga and double cream cheeses samples, with a mean values of $8 \times 10^{3} \pm 3 \times 10^{3}$, $2.0 \times 10^{2} \pm 9 \times 10,1.3 \times 10^{3} \pm 5 \times 10^{2}$ and $1 \times 10^{2} \pm 6 \times 10$, respectively. Egyptian standard (2005) stated that cheese samples must be free from $E$. coli, according to these standard 40,20, 24 and $12 \%$ of examined Kareish, Damietta, Tallaga and double cream cheeses samples were not complying with this limits as shown in table (8).

Lower results of $E$. coli incidence in soft cheeses samples obtained by Sayed et al. (2011) who reported that 4 and $12 \%$ of examined Damietta and Tallaga cheese had E. coli count above limits stated by Egyptian standard with average count 40 and 22.2, respectively, also, Hassan and Elmalt (2008) reported that E. coli was recovered from $11(47.8 \%)$ of Kareish cheese samples. While, higher results of $E$. coli incidence obtained by Baraheem et al. (2007) who reported that E. coli was detected in $60(75 \%)$ of examined kareish samples with mean \pm SD values $3.8 \times 10^{2} \pm 8.1 \times 10^{2}$ and $4.4 \times 10 \pm 9.9 \times 10$, in opened and packaged kareish cheese respectively. Hassan and Gomaa (2016) reported that E. coli was detected in 6 $(12 \%), 9(18 \%), 9(18 \%)$ and $14(28 \%)$ of the examined Damietta and Kareish cheese in Cairo and
Giza respectively. On the other hand, E. coli could be detected in soft cheese by Araujo et al. (2002) and Abd Elaal (2008) with incidences of 97.7 and $28 \%$ respectively.

The high incidence and count of $E$. coli in the examined cheese samples reveal lack of proper sanitation and give good indication about faecal contamination as E. coli constituted a part of normal intestinal flora in human and some animals (WHO 1995).

Table 7 revealed that the incidence of mould was 72 , 56, 64 and $40 \%$ in examined Kareish, Damietta, Tallaga and double cream cheeses samples, respectively. With a mean values $2.5 \times 10^{4} \pm 6 \times 10^{3}$, $4 \times 10^{3} \pm 1 \times 10^{3}, 2.2 \times 10^{3} \pm 6 \times 10^{2}$ and $6 \times 10 \pm 2 \times 10^{3} \mathrm{cfu} / \mathrm{g}$, respectively. While its range were $<10$ to $9.5 \times 10^{4}$, $<$ 10 to $2.0 \times 10^{4}$, < 10 to $1.5 \times 10^{4}$ and $<10$ to $3.0 \times 10^{4}$ $\mathrm{cfu} / \mathrm{g}$, respectively. Egyptian standard (2005) allow maximum possible of mould count in cheese not more than 10 cells /g, according to these standard 72, 56, 64 and $40 \%$ of examined Kareish, Damietta, Tallaga and double cream cheeses samples were not complying with this limits as shown in table (8).

The obtained results agree with Sayed et al. (2011) who reported that 52 and $84 \%$ of examined Damietta and Tallaga cheese had yeast and mouldcount above limits stated by Egyptian standard with average count $7.7 \times 10^{4}$ and $1.2 \times 10^{5}$, respectively. Hassan and Gomaa (2016) reported that total yeasts and moulds count of examined Damietta cheese samples in Cairo and Giza were ranged from $2 \times 10^{2}$ to $2.4 \times 10^{6}$ with a mean value of $1.7 \times 10^{5} \pm 6.3 \times 10^{4}$ and from $1.6 \times 10^{2}$ to $6 \times 10^{5}$ with a mean value of $3.9 \times 10^{4} \pm 1.6 \times 10^{4}$, While in Kareish cheese samples were ranged from $8 \times 10^{2}$ to $3.5 \times 10^{6}$ with a mean value of $4.7 \times 10^{4} \pm 1.1 \times 10^{4}$ and from $6 \times 10^{2}$ to $3.4 \times 10^{6}$ with a mean value of $3.1 \times 10^{5} \pm$ $4.3 \times 10^{4} \mathrm{cfu} / \mathrm{ml}$, respectively.

The major sources of mould in cheese were found in air, equipment and the plastic films of packaging, where air is considered as the major source of cheese contamination (Kure et al. 2004). Presence of wild types of moulds is undesirable as they may influence the organoleptic characteristics of the cheeses and can produce mycotoxins which represent a potential health risk (Wouters et al. 2002).

The presence of moulds in cheese are objectionable, as they grow at a wide range of temperature and $\mathrm{pH}$ values, resulting in spoilage of the product. Their count is used as an index of storability and sanitary quality of the product. Such moulds and yeasts can cause gas and off flavor in cheese due to their proteolytic activity (Osama et al. 2014).

In conclusion, the current study indicated that some samples of soft cheese are of in ferior quality as result of they produced, handled and distributed under 
neglected sanitary measures. The presence of pathogenic bacteria may pose a risk for public health. Therefore, we recommended to implement immediate regulatory measures like good manufacturing practices as well as HACCP system to ensure microbiological safety of different soft cheese.

\section{REFERENCES}

AbdElaal, S.F.A. (2008): Microbiological research on some dairy products. Assiut Veterinary Medical Journal. Vol.54. No: 119.

Amer, A.A. (2002): Safety and quality of butter and cheese through mycological criteria. Ph.D. Thesis. Fac. Vet. Med., Alex. Univ. Egypt.

American Public Health Association (2004): Standard methods for the examination of dairy products. 17th Edition Edited by H. Michael Wehr and Joseph H. Frank, Washington, D.C., USA.

Araújo, V.S.; Pagliares, V.A.; Queiroz, M.L.P. and Freitas-Almeida, A.C. (2002): Occurrence Staphylococcus and enteropathogens in soft cheese commercialized in the city of Rio de Janeiro, Brazil. Journal of Applied Microbiology, v. 92, p. 1172-1177.

Association of Official Agricultural Chemists (AOAC) (2005): Official Methods of Analysis (18 th ed.) Washington, DC, USA.

Atherton, H.V. and Newlander, J.A. (1977): Chemistry and Testing of Dairy Products. $4^{\text {th }}$ Ed., AVI Publishing Co. Inc., Westport, Connecticut.

Awad, E.I.; Abdelfattah, M.E.; Abdelkaliek, A.A. and El-diasty, E.M. (2012): Prevalence of Ochratoxin in small and large scale produced roomy cheese in Sharkia Governorate. World Rural Observ., 4(3): 76-80.

Baraheem, O.H.; Hoda A El-Shamy; Wafaa, M.B. and Naglaa F. Gomaa (2007): Bacteriological Quality of Some Dairy Products (Kareish Cheese and Ice Cream) in Alexandria. J. Egypt Public Health Assoc., Vol. 82 No. (5 \& 6): 492-510.

Egyptian Standards 1008-1/(2005): Soft cheese. Part 1: General standard of soft cheese. Egyptian Organization for Standardization and Quality Control. Standard number 1008-1/2005.

Egyptian Standards 1008-3/(2005): Soft cheese. Part 3: Damietta cheese. Egyptian Organization for Standardization and Quality Control. Standard number 1008-3/2005 .

El-Sayed, A.M.; Hosney, I.M.; EL-Kholy, W.I.; ELDairouty, A.M. and Mohamed, H. Sahar, (2011): Microbiological evaluation of Egyptian white soft cheeses style. J. of American Sci. 7 (5): 517-526.

Food and Drug Administration (FDA) (2002): Bacteriological Analytical Manual. $9^{\text {th }}$ Ed., AOAC International, Arlington, VA, USA.
Gandomi, H.; Misaghi, A.; Basti, A.A.; Bokaei, S.; Khosravi, A.; Abbasifar, A. and Javan, A.J. (2004): Effect of Zatariamultiflora Boiss. essential oil on growth and aflatoxin formation by Aspergillusflavus in culture media and cheese., Food and chemical toxicology, 47, 2397-2400.

Ghibaudo, G. and Peano, A. (2010): Chronic monolateralotomycosis in a dog caused by Aspergillusochraceus.

Veterinary dermatology, 21(5), 522-526.

Gill, J.P.S.; Joshi, D.V. and Kwatra, M.S. (1994): Qualitative bacteriological survey of milk products with special reference to Staph. aureus. Indian J. Dairy Sci. 47: 680-682.

Halawa, M.A. and Moawad, A.A. (1999): Bacteriological quality of street-vended white soft cheese. Alex. J. Vet. Sci. 15: 855-864.

Hassan, G.M. and Gomaa, S.M. (2016): Microbiological Quality of Soft Cheese Marketed in Cairo and Giza Governorates. Alexandria Journal of Veterinary Sciences 2016, July. 50 (1): 18-23

Hassan, S.A. and Elmalt, L.M. (2008): Informally raw milk and Kareish cheese investigation on the occurrence of toxigenic Escherichia coli in Qena city, Egypt with emphasis on molecular characterization. Ass. Univ. Bull. Environ. Res. Vol. 11 No. 2, 35-42.

Hill, B.M. (1983): $\quad$ Enterotoxin-producing Staphylococcus aureus isolated from milk and dairy products. New Zealand J. Dairy Sci. Technol. 18: 59-62.

Hitchins A.D. (2003): Detection and enumeration of Listeria monocytogenes in foods. Chapter 101. In: Jackson GJ (coordinator), Bacteriological Analytical manual. $10^{\text {th }}$ ed., Revision A., AOAC Int. Gaithersburg M.D.USA.

Ibrahim, G.A.; Sharaf, O.M. and Abd El-Khalek, A.B. (2015): Microbiological Quality of Commercial Raw Milk, Damietta Cheese and Kareish Cheese. Middle East J. Appl. Sci., 5(1): 171-176.

Kamat, M.Y.; Sulebele, G. and Nairupama, Sabins (1991): A comparative evaluation of media for enumeration of enterotoxigenic Staphylococci by selective enrichment technique. J. Food Sci. Technol., India, 28(6): 381-383.

Kanka, M.; Kamaly, K.; Zedan, N. and Zaghlol, A. (2007): Acceleration of ripening of Domiati cheese by accelase and lipozyme enzyme. Egyptian J. Dairy Sci. 35: 75-90.

Kure, C.F.; Skaar, I. and Brendehaug, J. (2004): Mould contamination in production of semihard cheese. Int. J. Food Microbiology. 15(93):41-49.

Metwalli, S.A.H. (2011): Extended Shelf Life of Kareish Cheese by Natural Preservatives. Egypt. J. Agric. Res., 89 (2), 639-649.

Mohamed, Z.A. (2016): Incidence of mycobiota in some dairy products and its public health 
hazards. Master thesis. Fac. Vet. Med., Alex. Univ. Egypt.

Okura, M.H.; Rigobelo, E.C. and Ávila, F.A. (2010): Isolamento e identificação de patógenosemleite cru produzidonasmicrorregiões do Triângulo Mineiro, MG. Ars Veterinaria 21: 324-331.

Osama, M.S.; Gamal, A.I.; Nabil, F.T.; Baher, A.M.; Effat, Kawther El Shafei; Hala M.F. El-Din and Moussa M.A.S. (2014): Prevalence of some pathogenic microorganisms in factories Domiati, Feta cheeses and UHT milk in relation to public health sold under market conditions in Cairo. International Journal of Chem Tech Research. Vol.6, No.5, pp 28072814.

Oxoid Manual (2006): Culture media product descriptions. Compiled by E.Y. Bridson, $9^{\text {th }}$ Ed., Published by Oxoid Limited, Basingstoke, Hampshire, England.

Paulin, S.; Horn, B. and Hudson, J.A. (2011): Factors influencing staphylococcal enterotoxin production in dairy products. MPI Technical chose one Paper No: 2012/07.

Reps, A.; Drychowski, L.J.; Tomasik, J. and Niewska, K.W. (2002): Natamycin in ripening cheeses. Pakistan. Journal of Nutrition, 1(5): 243- 247.

Roberts, D. and Greenwood, M. (2003): Practical Food Microbiology. Third edition, Blackwell publishing Ltd.

Robinson, R.K. and Tamime, A.Y. (2002): Maintaining a clean working environment. In: Robinson, R.K. (Ed.), Dairy Microbiology Handbook, the Microbiology of Milk and Milk Products, 3rd ed. Wiley, New York, pp. 561591.
Salama, E.M.; Saad, A.H.; Enan, G.A. and Suzan, I. Youssef (2015): Incidence and Biocontrol of Staphylococcus aureus in some milk products. 2nd Conference of Food Safety, Suez Canal University, Faculty of Veterinary Medicine Volume I August 2015 Page 29-35

Sayed, M.; Ahmed, A. and Walaa, S. (2011): Microbiological evaluation of some Egyptian white soft cheeses. Benha Veterinary Medical Journal, special Issue (1):1-6.

Soomro, A.H.; Arain, M.A.; Khaskheli, M.X. and Bhutto, B. (2002): Isolation of Escherichia coli from raw milk and milk products in relation to public health sold under market condition at Tandojam. Pak. J. Nutr., 1(3): 151-152.

SPSS, (2008): Statistical Package for Social Science, Computer Software, IBM, SPSS Ver. 16.0, SPSS Company, London, UK.

Synge, B.A. (2000): Verocytotoxin producing Escherichia coli: a veterinary view. J. Appl. Microbiol. 88: 31S-37S.

Temelli, S.; Anar, S.; Sen, C. and Akyuva, P. (2006): Determination of microbiological contamination sources during Turkish white cheese production. Food Control, 17: 856-861.

Varnam, A.H. and Sutherland, J.S. (1994): In milk and milk products. Varnam and Sutherland eds. Chapman and Hall, London.

WHO, World Health Organization, (1995): Food technologies and public health. Geneva, WHO/FNU/95. 12.

Wouters, J.; Ayad, E.H.E.; Hugenholtz, J. and Smith, G. (2002): Microbes from raw milk for fermented dairy products. Int. Dairy J. 12(2):91-109.

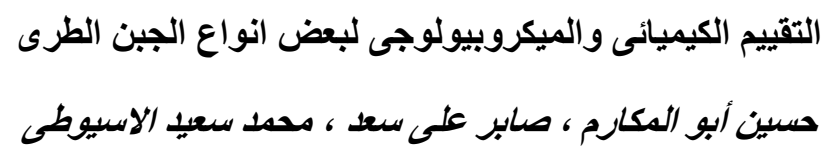

Email: mido_15158@hotmail.com

Assiut University web-site: www.aun.edu.eg

الجبن الطرى من أكثر أنواع الجبن المستهلكة فى مصر و هناك مصادر عديدة لتلوثها ولذلك تمت هذه الار استة لتقييم الجودة الكيميائية

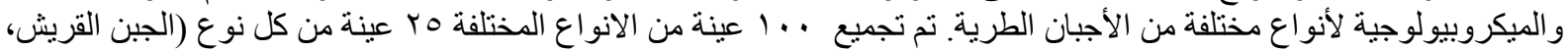

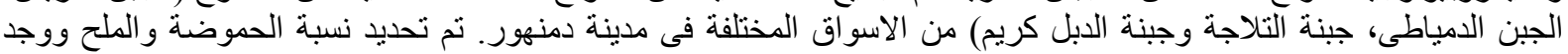
متوسط قيمتها الاحصائية كالاتي $1.97 \pm 0.18,2.84 \pm 0.5 ; 1.36 \pm 0.25,5.01 \pm 0.25 ; 1.0 \pm 0.19,2.99 \pm 0.17$ and

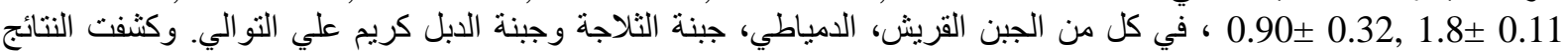

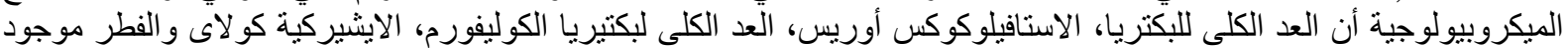

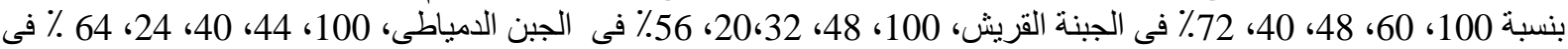

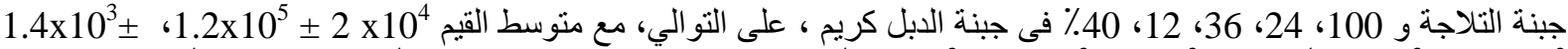

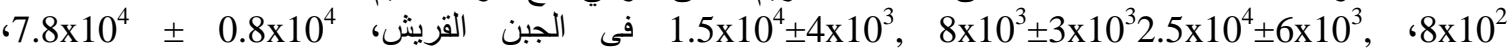

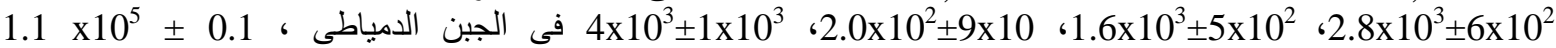

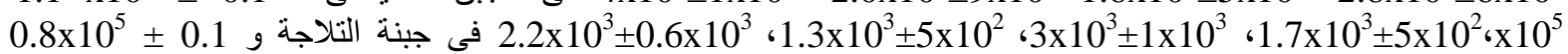

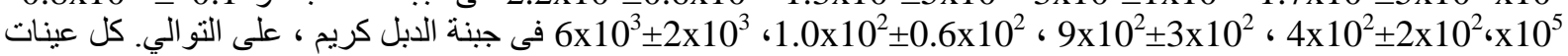

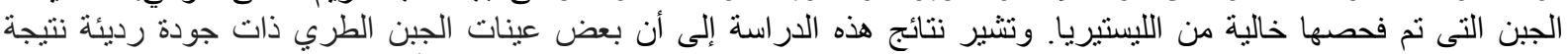

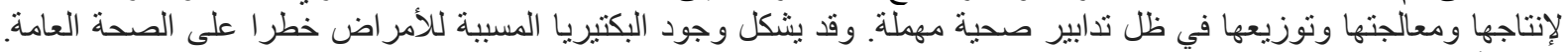

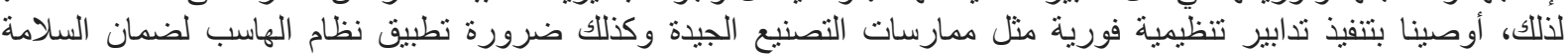
الميكروبيولوجية لمختلف أنواع الجبن الطرين فئنية فورية 